\title{
ОЦІНКА ЕКОНОМІЧНОГО ЕФЕКТУ ВІД ВПРОВАДЖЕННЯ УПРАВЛІНСЬКИХ ІНФОРМАЦІЙНИХ СИСТЕМ: ЗАГАЛЬНІ ПРИНЦИПИ ОЦІККИ
}

\author{
ASSESSMENT OF THE ECONOMIC EFFECT \\ OF IMPLEMENTING MANAGEMENT INFORMATION \\ SYSTEMS: GENERAL PRINCIPLES OF EVALUATION
}

\author{
Терещенко Лариса Олександрівна \\ кандидат економічних наук, профресор, \\ Український гуманітарний інститут \\ ORCID: https://orcid.org/0000-0003-0680-5259 \\ Tereshchenko Larisa \\ Ukrainian Institute of Arts and Sciences
}

\begin{abstract}
Ефективність управлінських інформаційних систем - це характеристика, яка відображає ступінь відповідності системи своєму призначенню, її технічній досконалості і економічній доцільності. У статті розглянуто питання загальні принципи оцінки економічного ефекту від впровадження управлінських інформаційних систем (УІС) та загальні принципи оцінки. Керівництво компанії повинно розуміти, яку вигоду принесе впровадження УІС компанії, наскільки ефективно, з економічної точки зору, зміниться виробничий процес під час використання системи. В статті обґрунтовано сутність, що визначає прямий економічний ефект від впровадження сучасної комплексної системи управління підприємством - системи ERP. Надані рекомендації та пропозиції щодо вибору методів та моделей в оцінці переваг ефективності IT-проєктів. Схарактеризовано загальні принципи і підходи, правила щодо процесу оцінки незалежно від методики оцінки, що використовується.

Ключові слова: управлінські інформаційні системи, принципи оцінки, економічні показники, методи, методики, управлінські рішення.
\end{abstract}

Эфффективность управленческих информационных систем - это характеристика, которая отображает степень соответствия системы своему назначению, ее техническому совершенству и экономической целесообразности. В статье рассмотрены вопросы оценки экономического эфффекта от внедрения управленческих информационных систем (УИС) и общие принципы оценки. Руководство компании должно понимать, какую выгоду принесет компании внедрение УИС, насколько эфффективно, с экономической точки зрения, изменится производственный процесс во время использования системы. В статье обоснована сущность, которая определяет прямой экономический эффрект от внедрения современной комплексной системы управления предприятием - системы ERP. Предоставленны рекомендации и предложения относительно выбора методов и моделей в оценке преимуществ эфрфективности IT-проектов. Охарактеризованы общие принципы, подходы и правила относительно процесса оценки независимо от методики оценки, которая используется.

Ключевые слова: управленческие информационные системы, принципы оценки, экономические показатели, методы, методики, управленческие решения.

An important issue is the assessment of the economic effect of the implementation of management information systems (MIS). The company's management must understand the benefits of implementing the company's MIS, how effectively, from an economic point of view, the production process will change during the use of the system. Therefore, the main purpose of the work is to develop a scientifically sound approach to the selection and implementation of MIS to ensure effective management of production resources and management decisions as well as research in identifying and disclosing general principles for assessing the economic effect of implementing management information systems. The general principles and approaches, rules on the evaluation process regardless of the evaluation methodology used are described, namely: the need to understand and describe the objectives of the evaluation process; awareness and description of the priorities of business goals; description of positive and negative IT factors in terms of business with the involvement of leading experts and company management; differentiation of sources of payback of IT projects through: one-time reduction of the company's assets and permanent changes, including sales growth and reduction of certain components of production costs; accounting for the time factor and 
the value of money. Information systems, in contrast to production, have a number of specific features, due to which the exact calculation of these economic indicators using standardized methods is difficult. The article considers the issue of assessing the economic effect of the implementation of management information systems (MIS). The article substantiates the essence that determines the direct economic effect of the introduction of a modern integrated enterprise management system - ERP system. The expected improvements achieved through the ERP system can be grouped into such categories, each of which has its own sources of payback. The abbreviation ERP is used to denote complex enterprise management systems. ERP is a term introduced by the research firm Gartner Group to describe control systems. Recommendations and suggestions for the choice of methods and models in assessing the benefits of the effectiveness of IT projects are given.

Keywords: management information systems, evaluation principles, economic indicators, methods, techniques, management decisions.

Постановка проблеми. Впровадження управлінської інорормаційної системи повинно забезпечувати якість управління і сприяти підвищенню ефективності виробничої діяльності, економічних об'єктів. А якість інформаційної системи повинна визначається ефективністю та надійністю усіх її складових частин, як забезпечуючої так і фрункціональної. Метою дослідження $€$ виокремлення i розкриття загальних принципів оцінки економічного есректу від впровадження інсрормаційних систем в управлінні.

Аналіз досліджень і публікацій. Питання оцінки економічного ефректу від впровадження управлінських інформаційних систем та загальні принципи оцінки $є$ предметом дослідження багатьох вітчизняних та зарубіжних науковців: Карминский А.М., Жевага А.А., Некрасова Е., Терещенко Л.О., Гужко С., Шайкан А. В. Зазначені питання були увагою іноземних науковців як: Дуглас Хаббард, Девід Глассман, Боб Каулі, Ховард Рубін. Питання оцінки економічного ефректу перебувають у колі інтересів Diana Farrell, Terra Terwilliger, Allen P. Webb. Переважна більшість науковців у своїх дослідженнях висвітлюють теоретикометодологічні та практичні аспекти.

Формулювання цілей статті. Основною метою роботи $\epsilon$ розробка науково обґрунтованого підходу до вибору і впровадження УІС в промислових компаніях для забезпечення есрективного управління виробничими ресурсами і прийняття управлінських рішень

Виклад основних матеріалів дослідження. Одним з ключових чинників, що впливають на інформаційну продуктивність компаній, і відповідно, бізнес-продуктивність, $€$ есрективний контроль і достовірний аналіз прямих і непрямих витрат на інорормаційну систему (IC), прийняття на основі одержанихданих своєчасних і збалансованих рішень щодо розподілу бюджету на IC, оптимізація наявних ресурсів ефрективного розвитку і підтримки працездатності IC, а також визначення пріоритетів інвестування.
Традиційно, інвестиції в бізнес і якісні характеристики вкладень у випуск продукції мають певні методики для оцінки їхньої цінності і визначення тенденцій. Особливістю інвестицій у виробництво євідносна простота аналізу співвідношень витрати/дохід, прибутковості інвестицій, прибутковості активів та інших показників бізнесу. Інформаційні ж системи, на відміну від виробництва, мають специфрічних особливостей, завдяки яким точний підрахунок зазначених економічних показників за допомогою стандартизованих методик ускладнений. Перш за все в цьому «винні» ті, хто експлуатує наявні технології, і визначає міру есрективної взаємодії з ресурсами.

Середовище функціонування промислових компаній потребує від топ-менеджерів швидкого і якісного реагування на зміни кон'юнктури ринку, прийняття кваліфрікованих, адекватних рішень, заснованих на сучасних економічних методах управління, а не на інтуїції. Як показують дослідження, витрати на управління виробництвом складають 1-2 \% від сумарних витрат компанії. Водночас управляти великими компаніями 3 максимальною віддачею неможливо без створення повноцінної управлінської інфрормаційної системи [1].

Важливим питанням стає оцінка економічного ефректу від впровадження УІС. Керівництво компанії повинно розуміти, яку вигоду принесе впровадження УІС компанії, наскільки есрективно з економічного погляду зміниться виробничий процес під час використання системи. Найгостріше питання вибору УІС торкається промислових компаній з територіально розподіленою структурою.

Основною метою роботи $є$ розробка науково обґрунтованого підходу до вибору і впровадження УІС в промислових компаніях для забезпечення есрективного управління виробничими ресурсами.

Ефрективність - міра того, наскільки добре специярічне завданнявиконується в порівнянні з певним стандартом. Наприклад, кіль- 
кість операцій або кількість людей, задіяних для цього. Але ефективність не дає відповіді на питання, чи $є$ специфічна діяльність відповідною до очікуваних результатів. Тому правильним підходом буде одержання відповіді не тільки на запитання - наскільки швидко ми розв'язуємо поставлені завдання?, але й на більш важлива - наскільки швидко й ефективно ми розв'язуємо поставлені завдання за оптимального співвідношення завантаженняресурсів і їх ділових показників, наприклад, розміру створеної доданої вартості?

Основні проблеми в оцінки витрат, що постають перед керівниками IC викликані такими причинами:

- брак точних і достовірних методик оцінки фрінансових показників IC 3 урахуванням вітчизняної специфріки;

- брак єдиного корпоративного стандарту або підходу до оцінки впливу чинника непрямих витрат на погіршення або поліпшенняекономічних характеристик IСзагалом та інформаційних активів зокрема;

- неефективний контроль витрат на IC i оцінки дієвості рішень, що приймаються;

- наявність великої кількості чинників, що впливають на чутливість аналізу.

Для того, щоб виділити головні категорії резервів поліпшення роботи компанії, які можуть бути реально використані за допомогою інсрормаційних систем, необхідно виділити найбільш типові чинники неефективності (тобто проблеми, властиві компанії). Ними в більшості компаній можуть бути:

- надмірний обсяг незавершеного виробництва;

- надмірні складські запаси;

- низький ступінь використання виробничих ресурсів;

- завищені матеріальні витрати;

- низька якість;

- низький рівень обслуговування клієнтів;

- неточності у визначенні собівартості і ціноутворення;

- недостатній рівень організації зберігання і логістики;

- проблеми обліку й управління фрінансами.

Так з'явилася концепція ERP (Enterprise Resource Planning - планування ресурсів компанії), названа іноді також плануванням ресурсів в масштабі компанії (Enterprise-wide Resource Planning). Абревіатура ERP використовується для позначення комплексних систем управління підприємством. ERP - термін, введений дослідницькою фрірмою Gartner Group для опису систем управління.
B основі ERP лежить принцип створення єдиної бази даних (репозітарія), що містить всю ділову інфрормацію, накопичену організацією в процесі ведення бізнесу, зокрема фрінансову інформацію, дані, пов'язані з виробництвом, управлінням персоналом, і будь-які інші дані. Наявність репозітарія позбавляє від необхідності передавати дані від одного додатку до іншого. Крім того, будь-яка частина інсрормації, яку має в своєму розпорядженні дана компанія, стає одночасно доступною для всіх працівників, що володіють відповідними повноваженнями. Концепція ERP знайшла широке застосування, оскільки планування ресурсів дозволяло скоротити час випуску продукції, знизити рівень товарно-матеріальних запасів, а також поліпшити зворотний зв'язок із споживачем при одночасному скороченні адміністративного апарату. Стандарт ERP дозволив об'єднати всі ресурси компанії і підвищити ефективність управління ними. Зараз практично всі сучасні системи управління виробництвом базуються на концепції ERP і відповідають іiі рекомендаціям. Комплексна інфрормаційна система управління компанією (ERP) - це найважливіший і незамінний інструмент ефрективного управління ресурсами компанії. Єдине інформаційне середовище стає могутнім засобом збору і аналізу фрінансової інфрормації - це шлях до реального підвищення конкурентоспроможності і прибутковості, до залучення інвестицій, а значить - до максимальних темпів зростання бізнесу. Досвід зарубіжних компаній показує, що етап вибору системи управління компанією $€$ одним 3 найважливіших, i керівництво компанії має бути зацікавлено у виборі правильного рішення. Будь-який проєкт в ссрері автоматизації повинен розглядатисякомпанією як стратегічне вкладення, яке повинне окупитися за рахунок удосконалення управлінських процесів, підвищення ефрективності виробництва, скорочення витрат, і ставитися на один рівень з придбанням, наприклад, нової виробничої лінії або будівництвом цеху. Від успішності вирішення даного завдання, в значній мірі залежить, наскільки успішним буде весь проєкт щодо впровадження системи автоматизації управління компанією і чи вдасться добитися очікуваного ефекту [3].

Очікувані поліпшення, досягаються за допомогою концепції ERP, можуть бути згруповані в категорії, для кожної з яких характерні свої джерела окупності (табл. 1).

Для виявлення прихованих резервів необхідно визначити стадії виробничого процесу, які не підвищують цінності кінцевого продукту. 
Таблиця 1

Очікувані поліпшення, що досягаються за допомогою ERP-системи

\begin{tabular}{|c|c|}
\hline Категорії поліпшень & Джерела окупності \\
\hline \begin{tabular}{|l|} 
Незавершене \\
виробництво і тривалість \\
виробничого циклу \\
\end{tabular} & $\begin{array}{l}\text { Зниження вкладень в активи, зниження витратна переміщення } \\
\text { матеріалів, скорочення термінів виробництва, зниження запасів } \\
\text { напівфрабрикатів власного виробництва }\end{array}$ \\
\hline Складські запаси & $\begin{array}{l}\text { Зниження вкладень в активи, зниження витрат на переміщення } \\
\text { матеріалів, підвищення рівня обслуговування }\end{array}$ \\
\hline \begin{tabular}{|l} 
Використання \\
виробничих ресурсів
\end{tabular} & $\begin{array}{l}\text { Зниження втрат робочого часу, мінімізація переналагоджень, } \\
\text { підвищення коефріцієнта готовності устаткування }\end{array}$ \\
\hline $\begin{array}{l}\text { Зниження матеріальних } \\
\text { витрат }\end{array}$ & $\begin{array}{l}\text { Партнерські відносини з постачальниками, своєчасність вхідних } \\
\text { постачань, можливість використання невеликих партій, зниження } \\
\text { частки бракованих матеріалів }\end{array}$ \\
\hline $\begin{array}{l}\text { Підвищення якості } \\
\text { продукції }\end{array}$ & $\begin{array}{l}\text { Зменшення браку, зниження порушень графріків виробництва, } \\
\text { зменшення кількості переналагоджень, запобігання зниженню } \\
\text { обсягів продажу }\end{array}$ \\
\hline $\begin{array}{l}\text { Підвищення якості } \\
\text { обслуговування }\end{array}$ & $\begin{array}{l}\text { Зниження термінів постачань, забезпечення відповідності між } \\
\text { запасами готової продукції та клієнтським попитом, своєчасність } \\
\text { постачань, інтенсифрікація спілкування з клієнтами }\end{array}$ \\
\hline Управління витратами & $\begin{array}{l}\text { Оперативність і точність розрахунку собівартості, можливість } \\
\text { оперативного аналізу витрат, можливість аналізу причин відхилень } \\
\text { від плану, визначення найбільш рентабельних видів продукції }\end{array}$ \\
\hline $\begin{array}{l}\text { Організація, зберігання і } \\
\text { переміщення матеріалів }\end{array}$ & $\begin{array}{l}\text { Підвищення есрективності за одночасного зниженні трудомісткості, } \\
\text { підвищення якості обслуговування, більш точний і оперативний } \\
\text { контроль }\end{array}$ \\
\hline $\begin{array}{l}\text { Облікі управління } \\
\text { фрінансами }\end{array}$ & $\begin{array}{l}\text { Доступність точної і своєчасної фрінансової інформації, оптимізація } \\
\text { фрінансових відносин з постачальниками і споживачами }\end{array}$ \\
\hline
\end{tabular}

Такі процеси і операції можна розбити на дві категорії, а саме:

1. Процеси й операції, технологічно та економічно обґрунтовані, алетакі, що не підвищують цінності кінцевого продукту.

2. Процеси й операції, пов'язані 3 необґрунтованими витратамиресурсів і часу (очікування, простої, зберігання зайвихзапасів).

Можна виявити конкретні сфери впливу частин (модулів) інформаційних систем. Відповідно до фрункціональності модулі можна поділити на п'ять категорій:

1. Стратегічне планування, бюджетування, фрінанси й облік.

2. Маркетинг і дистрибуція.

3. Розробка нової продукції.

4. Планування й управління виробництвом і матеріальними потоками.

5. Оперативне управління виробничими операціями.

Згідно зі статистикою, запропонованого APICS (American Production and Inventory Control Society - Американське суспільство по управлінню виробничими запасами), впровадження сучасної ERP-системи може забезпечити таку віддачу:

- зменшення страхових запасів - (- 40\%);

- зменшення складських площ- (- 25\%);
- збільшення оборотності ТМЗ - (+ 65\%)

- збільшення обсягу постачань вчасно $(+80 \%)$;

- зниження кількості затримок з відвантаженням ГП - (- 45\%);

- більш точний облік витрат - (+ 30\%);

- зменшення термінів закриття облікового періоду - (- 500\%);

- збільшення оборотності засобів в розрахунках - (+30\%);

- зменшення витрат на адміністративноуправлінський апарат - (- 30\%);

- усунення ручної підготовки і супроводу документів - (+ 90\%);

- скорочення незавершеного виробництва (Н3B) - (- 50\%);

- скорочення виробничого циклу - (- 50\%);

- скорочення циклу розробки нових продуктів - (- 50\%);

- скорочення часу складання бюджету (- 70\%) [4].

Отже, збільшується ліквідність компанії за рахунок:

- зміни структури її активів;

- зменшення в частині оборотних активів дебіторської заборгованості;

- більш ефективного використання засобів компанії за рахунок збільшення загальної 
оборотності як всього капіталу в цілому, так і окремих його частин;

- зниження потреби компанії в оборотних коштах за рахунок підвищення ритмічності роботи;

- зменшення запасів і впровадження прогресивних методів їх плануванняі контролю.

Це основні елементи, що визначають прямий економічний ефект від впровадження сучасної ERP-системи. Для того, щоб оцінити віддачу від впровадження ERP-системи у конкретній компанії в грошовому виразі, треба співвіднести приведені вище показники з реальними фрінансовими показниками компанії.

Разом 3 цим для усвідомлення ефективності інвестицій в IT необхідно розглядати і не грошові «бонуси» підвищення ефективності компанії, а саме:

- підвищення «інтелектуальності» бізнесу (оперативна наявність великих обсягів релевантної інфрормації дозволяє керівникові прийняти перспективне, запобіжне рішення);

- оптимізація планування (своєчасний доступ усіх зацікавлених користувачів до важливої інфрормації, що знаходиться в одній централізованій базі даних - БД);

- удосконалення процесів прийняттярішень (рішення стають більш обґрунтованими, якщо вони підкріплені достовірною й оперативною інформацією і крім того, заощаджується час, що використовувався раніше, на аналіз другорядних деталей);

- розширення інформаційної компетентності (чим більша кількість працівників має доступ до корпоративних даних, тим «розумніше» стає організація в цілому);

- створення єдиного середовища співпраці (організація набуває могутнього заряду розвитку, адже кожний з ії̈ членів працює на досягнення прозорих, зрозумілих i, головне, цілей).

Отже, впровадження ERP-системи слід розглядати як інвестиційний проєкт, спрямований на придбання нових конкурентних переваг і одержання реальної економічної віддачі від засобів, вкладених в систему.

На думку незалежних аналітиків бізнесу, «оцінка ефрективності IT-проєктів в Україні, та і у всьому світі, на сьогодні не наука, а мистецтво - методики ще тільки відпрацьовуються, постійно коректуються з накопиченням досвіду за кожним конкретним проєктом, тому говорити про єдині підходи до вироблення критеріїв і алгоритмів оцінки поки передчасно» [2].

У своїх проєктах 3 оцінки ефрективності корпоративних інфрормаційних систем використовується розробка - метод життєвого циклу штучних систем SLCA (System life cycle analysis). В його основі лежить вимірювання «ідеальності» системи - відношення їі корисних чинників до суми шкідливих і чинників розплати за виконання корисних фрункцій. Процесу оцінки передує спільна робота бізнес-аналітика, що веде фрахівців компанії до вироблення реєстру корисних, негативних і витратних чинників системи бізнесу без інфрормаційної системи і присвоєння їм певних значень. Потім складається розрахункова модель, що описує стан без IC. Після цього в модель уводяться описані чинники змін і проводитьсярозрахунок значення рівня розвитку системи бізнесу з IC. Метод SLCA застосовується на наступних етапах:

- передпроектної підготовки для попередньої оцінки есректу від упровадження нової системи або від модернізації наявної;

- розробки тактико-технічного завдання (ТT3) IC для розділу «Очікувані техніко-економічні результати створення IC»;

- проведення системно-аналітичного обстеження компанії для проектної оцінки ефректу, що очікується;

- прийняття системи до експлуатації (або після закінчення періоду дослідної експлуатації) для підтвердження розрахункового ефректу, його уточнення і отримання нової «точки відліку» (нового рівня організаційнотехнологічного розвитку компанії) для подальших оцінок ефекту від впроваджень нових IC.

Однією 3 таких найбільш відомих методик $є$ метод збалансованої оцінної відомості (Balanced Scorecard). Суть полягає у визначенні точних причинно-наслідкових зв'язків між технологією і фрінансовими показниками, виходячи з твердження, що кожна дія, яка стосується інформаційних технологій (IT), має відбивати стратегічну мету певної компанії. На першому етапі визначається причинно-наслідковий зв'язок між фрінансовими показниками і стратегією на найвищому рівні компанії, потім визначаються й аналізуються внутрішні процеси, зокрема стимулюючий розвиток технології, щоб допомогти добитися цих результатів. Традиційні бухгалтерські показники фрінансового компанії «балансуються» за допомогою оцінки трьох видів діяльності, а саме: роботи із замовниками, оперативності і здібності організації до навчання і вдосконалення [2].

Що стосується суті методики AIE (Applied information economics), розробленої Дугласом Хаббардом, керівником компанії Hubbard Ross, полягає в оцінці переваг, що компанія одержуєвід реалізації IT-проєкту, не у фрінан- 
совому, а в натуральному виразі. У процесі оцінки відбувається присвоєння одиниць традиційним нематеріальним активам, таким як рівень задоволеності користувачів і стратегічна орієнтація, а потім іде визначення цінності інформації різними інструментальними засобами, запозиченими з теорії управління порторелем активів і теорії статистики. Такий підхід дозволяє піддавати аналізу різні стратегії зневизначеними результатами, як це часто буває при інвестиціях в IT.

Методика споживчого індексу (customer index) була розроблена компанією Andersen Consulting і спочатку орієнтована на іпотеки, банківські операції та інші фрінансові напрями, пов'язані 3 обслуговуванням великої кількості клієнтів. Метод припускає оцінку впливу інвестицій в технології на чисельність і склад споживачів. У процесі оцінки компанія визначає економічні показники своїх споживачів за рахунок відстежування доходів, витрат і прибутків щодо кожного замовника окремо. Істотність методу полягає в несормалізованості процесу встановлення прямого зв'язку між інвестиціями в IT і збереженням або збільшенням числа споживачів. Ця методика застосовується в основному для оцінки ефективності IT-проєктів компаній, у яких чисельність замовників безпосередньо впливає на всі аспекти бізнесу.

Компанія Stern Stewart пропонує погляд на IT-підрозділ як на «державу в державі». Hа думку фрахівців Stern Stewart, фрахівці IT-підрозділу повинні продавати свої послуги всередині компанії за розцінками, приблизно еквівалентними розцінкам на зовнішньому ринку, що дозволить компанії відстежувати як доходи, так і витрати на IT. Отже, IT-структура з традиційного центру витрат перетворюється на центр прибутку, і з'являється можливість чітко визначати, як витрачаються активи, пов'язані з IT, і збільшуються доходи акціонерів. Девід Глассман, керівник Stern Stewart за стратегічними ініціативами стверджує «Пов'язавши параметри Economic value added (EVA) з ініціативами, які дозволяють ефективно використовувати ці параметри, ви доб'єтеся значно вищих фрінансових результатів, Роботу буде надано ліпшим, більше людей стануть піклуватися про доходи акціонерів» [2].

В основі Economic value sourced (EVS) лежить метод управління ризиками. На думку Боба Каулі, першого віце-президента оріліалу компанії Meta Group i розробника плану оцінки EVS, IT-технології можуть принести компанії користь, а саме: збільшення доходів, підвищення продуктивності, скорочення часу на випуск продукції, а також знизити ризик.

Методика припускає точний розрахунок усіх можливих ризиків і вигод для бізнесу, пов'язаних з упровадженням і фрункціонуванням корпоративної інсрормаційної системи. При цьому розширюється використання таких інструментальних засобів для оцінки IT, як EVA, внутрішня норма прибутку (англ. internal rate of return, IRR) і активи від інвестицій (англ. return on investmen, $R O I)$, за рахунок визначення і залучення в оцінний процес параметрів часу і ризику.

Управління портфелем активів (portfolio management) припускає, що компанії управляють IT так само, як управляли б акціонерним інвестиційним фоондом з урахуванням обсягу, розміру, терміну, прибутковості і ризику кожної інвестиції. Керівник інформаційної служби розглядається як менеджер фонду. Автор методики Ховард Рубін, виконавчий директор компанії Rubin Systems і науковий працівник Meta Group говорить: «У компанії необхідне панування уявлення про те, що технологія це інвестиції, які повинні постійно працювати, як на фрінансових ринках».

Основу методики Real option valuation (ROV) складає ключова концепція гнучких можливостей компанії в майбутньому. Методика розглядає IT як набір можливостей 3 великим ступенем їх деталізації. Правильне рішення приймається після ретельного аналізу широкого спектра показників і розгляду безлічі результатів або варіантів майбутніх сценаріїв, які в термінах методики йменуються «динамічним планом випуску» управлінських рішень, або майбутніх подій. Мета методики полягає в тому, щоб добитися максимального рівня гнучкості, який, в свою чергу, допоможе компаніям краще і набагато швидше адаптуватися або змінювати свій курс в сорері IT [2].

Стрімке розповсюдження нових технологій, позитивно впливаючи на економіку в цілому, для окремих компаній може означати швидку втрату переваг. Як тільки основна маса компаній галузі впроваджує якийсь стандартний набір додатків, IT перетворюються просто на чергову статтю витрат, а не в джерело конкурентної переваги. Цілком природно, що найшвидше і більш охоче конкуренти впроваджують найпростіші IT-рішення, ті, що вимагають мінімуму попередньої роботи. Проте завдяки деяким технологічним нововведенням дійсно створюються нові продукти, процеси або послуги. У компанії істотно зміцнюють ті переваги, що вже є у них. При цьому компанії праг- 
нуть захистити свої рішення і роблять так, щоб їх було важко скопіювати.

Унікальність забезпечується тим, що IT-система пов'язана 3 характерними особливостями компанії, наприклад масштаб або ії значний інтелектуальний капітал. Зрозуміло, компаніям, що прагнуть використовувати нові технології, які підвищують продуктивність і в той же час їх можна зберегти в таємниці від конкурентів, доводиться шукати відповіді на непрості запитання, а саме: як знайти об'єкти для інвестицій, щоб компанія вирвалася уперед? Як планувати обсяг і час інвестицій, щоб в умовах конкурентної боротьби придбати матеріальні цінності, що мають справжню довготривалу вартість?

щоб знати, які технології дозволять компанії виділитися 3-поміж її конкурентів, треба визначити, впливаючи на які операційні важелі вона одержить максимальну надбавку в продуктивності. Деякі з цих важелів свідомо важливіші за інші. їх значення іноді істотно залежить від галузі або від моделей бізнесу. Виявивши джерела збільшення продуктивності, компаніям слід вибрати ссрери, в яких за допомогою нових технологій можна створити реальні конкурентні переваги [4].

Висновки. Керівництво компанії повинно розуміти, яку вигоду принесе компанії впровадження УІС і наскільки ефективно з економічного погляду зміниться виробничий процес під час використання інформаційної системи. Фахівці, що оцінюють ефективність IT-проєктів на всіх стадіях реалізації проєкту, повинні виділяти загальні принципи оцінки і, незалежно від методики оцінки. підходи щодо процесу оцінки.

\section{СПИСОК ВИКОРИСТАНИХ ДЖЕРЕЛ:}

1. Карминский А. М., Жевага А. А. Принципы оценки экономического эфффекта от внедрения управленческой инсормационной системы на предприятии с территориально распределённой структурой. URL: http://www.cfin.ru (дата звернення: 13.07.2021).

2. Некрасова Е. Информационная система предприятия: эфффекты или эфрфективность? Management.com.ua URL: http://www.management.com.ua/ims/ims064.html (дата звернення: 12.07.2021).

3. Терещенко Л. О., Гужко С., Шайкан А. В. Управлінські інформаційні системи : підручник. Київ : КНЕУ, 2008. $485 \mathrm{c}$.

4. Farrel D., Terwilliger T., Webb A. Р. Оправданные технологии. Management.com.ua URL: http://www.management.com.ua/ims/ims067.html (дата звернення: 07.06.2021).

\section{REFERENCES:}

1. Karminskij, A. M., \& Zhevaga, A. A. (n. d.). Principy ocenki ekonomicheskogo effekta ot vnedreniya upravlencheskoj informacionnoj sistemy na predpriyatii s territorial'no raspredelyonnoj strukturoj [Principles for assessing the economic effect of the introduction of a management information system at an enterprise with a geographically distributed structure]. Retrieved from: http://www.cfin.ru (in Russian)

2. Nekrasova, E. (2004) Informacionnaya sistema predpriyatiya: effekty ili effektivnost'? [Information system of the enterprise: effects or efficiency]. Management.com.ua. Retrieved from: http://www.management.com.ua/ims/ ims064.html (in Russian)

3. Tereshchenko, L. O., Huzhko, C., \& Shaykan, A. V. (2008) Upravlins'ki informatsiyni systemy [Management information systems]. Kyiv: KNEU. (in Ukrainian)

4. Farrel, D., Terwilliger, T., \& Webb, A. P. (2004). Opravdannye tekhnologii [Justified technologies]. Management.com.ua. Retrieved from: http://www.management.com.ua/ims/ims067.html (in Russian) 